\title{
Soil Aggregate Stability and Associated Structure Affected by Long-Term Fertilization for a Loessial Soil on the Loess Plateau of China
}

\author{
Dengfeng Tuo ${ }^{1,2}$, Mingxiang Xü ${ }^{1 *}$, Qiang $\mathrm{Li}^{3}$, Sihan $\mathrm{Liu}^{4}$ \\ ${ }^{1}$ State Key Laboratory of Soil Erosion and Dryland Farming on the Loess Plateau, Institute of Soil and Water \\ Conservation, Northwest A\&F University, Yangling, Shaanxi 712100, China \\ ${ }^{2}$ State Key Laboratory of Urban and Regional Ecology, Research Center for Eco-Environmental Sciences, \\ Chinese Academy of Sciences, Beijing 100085, China \\ ${ }^{3}$ Yulin University, Yulin, Shaanxi 719000, China \\ ${ }^{4}$ College of Forestry, Northwest A\&F University, Yangling, Shaanxi 712100, China
}

Received: 31 August 2016

Accepted: 3 November 2016

\begin{abstract}
Agricultural management practices play an important role in soil structure and fertility. However, there is a lack of knowledge on the effects of long-term fertilization on aggregate structure in the Loess Plateau region in China. This study was devoted to examining the responses of soil aggregate stability and associated structure to fertilizers over 19 years under a soybean (Glycine max L.)-corn (Zea Mays) rotation. Treatments included unfertilized control $(\mathrm{CK})$; nitrogen $(\mathrm{N})$, phosphorus $(\mathrm{P})$, and NP chemical fertilizers; and manure (M) and MN, MP and MNP organic/chemical combinations. The results showed that the water-stable aggregates, mean weight diameter, geometric mean diameter, aggregate state, and aggregate degree decreased in chemical fertilizers (N, P, and NP). However, it increased in all treatments containing manure (M, MN, MP, and MNP) compared to the $\mathrm{CK}$. The changes in dispersion rate and fractal dimension were opposite to those indicators in all treatments. The applications of chemical fertilizers do guarantee an increase in crop yield, but only organic fertilizers significantly improved soil structure. These results suggest that manure's incorporation into loessial soil is a preferred strategy for sustainable soil management.
\end{abstract}

Keywords: chemical fertilizer, manure, aggregate structure, loessial soil

\section{Introduction}

Soil structure exerts important influences on the conditions and workability of soil. Optimal soil structure can decrease erodibility [1], support plants by regulating

*e-mail: xumx@nwsuaf.edu.cn water conditions, and optimize aeration levels and the release of available nutrients [2-3].

As an important agricultural practice, fertilization can change soil structure [4-6]. The effects of fertilizers on soil structure are complex and depend on the types of fertilizers, environmental conditions, fertilization regime, and initial soil $\mathrm{C}$ contents [7-8]. Some studies have reported that long-term applications of chemical fertilizers increased water-stable aggregation, porosity, and hydraulic 
conductivity, but decreased bulk density; these changes were attributed to the increased crop yields and returns of organic matter [9]. Other studies, however, have reported that the application of chemical fertilizers exacerbated clay dispersal, adversely affecting soil aggregation [3, 10]. Soil structure could thus be degraded with a reduction in aggregate stability. Simansky et al. [11] even reported that chemical fertilization (NPK) did not have statistically significant influence on increasing the soil structure stability of orthic luvisol. In addition, organic matter was a major contributor to aggregate stability because it provided important biological binding agents, which decreased the breakdown of aggregates by slaking, swelling, or even osmoting stress [7, 12-14]. Some studies have reported that aggregate stability was higher in soil fertilized with manure than in soil fertilized with chemical fertilizers [1516]. However, other studies have reported that the rate of organic input or soil characteristics (essentially $\mathrm{C}$ and clay contents) had no evident effect on aggregate stability [17$18]$.

Suitable measures for characterizing soil structure are necessary for evaluating the impact of fertilizer application on soil quality [3]. Three broad categories of soil structure are generally recognized: single-grained, massive, and aggregated [19]. An aggregated structure is the most desirable condition for plant growth and the most sensitive index of soil structure $[1,20]$. Water-stable aggregates (WSAs), mean weight diameter (MWD), and geometric mean diameter (GMD) have been widely used to analyze aggregate stability [21-23]. Moreover, aggregate state, aggregate degree, and dispersion rate determine the ability of soil to resist disturbance and serve as indicators of soil structure [24]. Fractal dimension is also a powerful tool used to characterize aggregate-sized distributions for monitoring soil structure [25-27]. Using the fractal method to estimate soil structure changes under practices in conventional tillage/no tillage rotation, Wang et al. [28] found that MWD and GMD were increased while fractal dimension decreased.

The Loess Plateau of China is characterized by concentrated precipitation, dry climate, intensive evaporation, and frequent natural disasters [29]. The loessial soil (Entisols in the USDA classification system) widely distributed in the region is characterized by silty loams of low fertility (soil organic matter content $6.15 \pm 2.4 \mathrm{~g} \mathrm{~kg}^{-1}$ ) and poor structural stability for resisting disturbances such as tillage and erosion [23]. To date, few studies have quantified the changes of soil aggregate structure caused by long-term fertilization on the hilly Loess Plateau. Unfavorable soil properties combined with inappropriate fertilization management, such as excessive chemical fertilization, a preference for nitrogen (N) fertilizers, and no manure application can lead to a significant degradation of soil structure and fertility $[2,10$, 30 ], which could further become serious obstacles to local agricultural development.

The long-term application of fertilizer provides a good opportunity formulating rational strategies for maintaining soil health [3, 31-32]. Based on the fundamental role of soil organic matter on the formation of aggregates, the study of the association between fertilization and soil structure could provide scientific and practical reference for the development of sustainable fertilization practices. The main objectives of this study were thus: 1) to determine the effects of different fertilization practices on soil aggregate stability and structure and 2) to offer an appropriate nutrient-supply strategy for local farmers based on a 19-year long-term fertilization system.

\section{Materials and Methods}

\section{Study Site}

The long-term fertilization experiment began in 1995 at the Ansai Field Experimental Station $\left(109^{\circ} 19^{\prime} \mathrm{E}, 36^{\circ} 51^{\prime} \mathrm{N}\right)$ in a typically hilly region of the Loess Plateau. The area has a semiarid climate with a mean annual temperature of $8.8^{\circ} \mathrm{C}$ and an average of 203 frost-free days. The mean annual precipitation in the area is $505 \mathrm{~mm}$, which falls mostly from July to September. The experimental plots are located on tableland along a river. The soil is typical cultivated loessial soil, which originated from wind deposits and is characterized by a yellow color, an absence of bedding, a silty texture, looseness, macroporosity, and wetness-induced collapsibility [33].

\section{Experimental Design}

The experimental field covered an area of $500 \mathrm{~m}^{2}$ and was divided into 24 plots. The plots received three replicates of eight treatments: unfertilized control (CK), $\mathrm{N}$ fertilizer $(\mathrm{N})$, phosphorus fertilizer $(\mathrm{P}), \mathrm{N}+\mathrm{P}$ fertilizer $(\mathrm{NP})$, manure $(\mathrm{M})$, manure $+\mathrm{N}$ fertilizer $(\mathrm{MN})$, manure $+\mathrm{P}$ fertilizer $(\mathrm{MP})$, and manure $+\mathrm{N}+\mathrm{P}$ fertilizer (MNP) (Table 1). The plots were $2.3 \times 6 \mathrm{~m}$ and were separated by $1-\mathrm{m}$ protection rows in a randomized complete-block design.

Two crops, soybean (Glycine max L.) and corn (Zea Mays), were grown in annual rotation. The crops were sown in April at densities of 10 plants $-\mathrm{m}^{2}$ for corn and 50 plants $-\mathrm{m}^{2}$ for soybean. Following the local convention, the organic (manure), $\mathrm{N}$ (pure $\mathrm{N}$ ), and $\mathrm{P}\left(\mathrm{P}_{2} \mathrm{O}_{5}\right)$ fertilizers were applied at rates of 500, 100, and $50 \mathrm{~kg} \mathrm{ha}^{-1}$,

Table 1. Fertilizer inputs to the treatments.

\begin{tabular}{|c|c|c|c|c|c|c|c|c|}
\hline Fertilizer & $\mathrm{CK}$ & $\mathrm{N}$ & $\mathrm{P}$ & $\mathrm{NP}$ & $\mathrm{M}$ & $\mathrm{MN}$ & $\mathrm{MP}$ & $\mathrm{MNP}$ \\
\hline Manure & & & & & + & + & + & + \\
\hline $\mathrm{N}$ & & + & & + & & + & & + \\
\hline $\mathrm{P}$ & & & + & + & & & + & + \\
\hline
\end{tabular}

Note: CK, unfertilized but cropped control; N, nitrogen fertilizer; P, phosphorus fertilizer; NP, N+P fertilizer; $\mathrm{M}$, manure; $\mathrm{MN}, \mathrm{M}+\mathrm{N}$ fertilizer; $\mathrm{MP}, \mathrm{M}+\mathrm{P}$ fertilizer; $\mathrm{MNP}$, $\mathrm{M}+\mathrm{N}+\mathrm{P}$ fertilizer. + indicates the input of fertilizer. 
respectively. The organic and $\mathrm{P}$ fertilizers were applied once at sowing. The $\mathrm{N}$ fertilizer was applied twice $-36 \%$ as a basal fertilizer and the remainder as a top-dressing at the jointing stage. The soil was plowed by donkeys before sowing each year and was manually hoed once during the growing season. Residual plant material above the ground was removed from the plots after harvest at the beginning of October.

\section{Soil Sampling}

Soil samples were collected from the $0-20 \mathrm{~cm}$ layer of all plots after the crop harvest in October 2014. Undisturbed soil samples with dimensions of $20 \times 10 \times 5$ $\mathrm{cm}$ were obtained using a spade from five random points in each plot for macroaggregates. Composite soil samples were collected from the same plots. After air-drying and removing visible pieces of crop residues and roots. Part of these samples were ground to pass through a 2-mm sieve for microbial biomass carbon (MBC), microaggregateand particle size distribution measurements, and the remainder was ground to pass through a $0.25-\mathrm{mm}$ sieve for soil organic carbon (SOC) and total nitrogen (TN) analysis.

\section{Soil Analysis}

Soil macroaggregates were measured using wetsieving method [34]. Five size classes $(>5,2-5,1-2,0.5-1$, $0.25-0.5 \mathrm{~mm}$ ) were obtained with sieves of $5,2,1,0.5$, and $0.25 \mathrm{~mm}$. Water-stable aggregates (WSAs) $>0.25 \mathrm{~mm}$ were considered as macroaggregates. Soil microaggregates and particles were analyzed by a Mastersizer 2000 laser diffraction device [35]. For microaggregate determination, the samples were presoaked with distilled water for $24 \mathrm{~h}$. For particle determination, samples were pretreated with $6 \% \mathrm{H}_{2} \mathrm{O}_{2}$ to remove organic matter and we added $10 \% \mathrm{HCL}$ for removing carbonates and oxides, and then soaked them with distilled water for $24 \mathrm{~h}$. After removing the distilled water, the samples were chemically dispersed with $0.4 \%$ Calgon and mechanically dispersed in an ultrasonic bath for 30 seconds [24]. SOC was determined using the Walkley-Black method [36]. TN was determined by the Kjeldahl method [37]. MBC was measured by the fumigation-extraction method [38].

\section{Calculation of Soil Aggregate Structure Index}

MWD (mm) and GMD ( $\mathrm{mm})$, indices of aggregate stability were calculated as [15]:

$$
M W D=\sum_{i=1}^{n} \overline{R_{i}} w_{i}
$$

$$
G M D=\exp \left[\sum_{i=1}^{n} w_{i} \ln \overline{R_{i}} / \sum_{i=1}^{n} w_{i}\right]
$$

...where $\bar{R}_{i}$ is the average diameter of the openings of two consecutive sieves, and $w_{i}$ is the weight ratio of the aggregates retained by sieve $i$. The ratio of the weight of the aggregates retained by each sieve $(>5$, $2-5,1-2,0.5-1$, and $0.25-0.5 \mathrm{~mm}$ ) to the total weight of the aggregates was calculated for determining aggregate distribution.

Aggregate state (AS), aggregate degree (AD), and dispersion rate (DR) were proposed to evaluate soil aggregate structure via the following equations [24]:

$$
\begin{gathered}
A S=n_{1}-n_{2} \\
A D=A S / n_{2} \times 100 \% \\
D R=n_{3} / n_{4} \times 100 \%
\end{gathered}
$$

...where $n_{1}$ is the content of microaggregates $>0.05 \mathrm{~mm}$, $n_{2}$ is the content of particles $>0.05 \mathrm{~mm}, n_{3}$ is the content of microaggregates $<0.05 \mathrm{~mm}$, and $n_{4}$ is the content of particles $<0.05 \mathrm{~mm}$.

The fractal dimension (D) of the soil aggregates was determined by Tuo et al. [39]:

$$
M\left(r<R_{i}\right) / M_{T}=\left(R_{i} / R_{\max }\right)^{3-D}
$$

... where $R_{i}$ is the mean aggregate diameter (mm) of size class $i, M\left(r<R_{i}\right)$ is the cumulative mass of aggregates of size $r$ less than $R_{i}, M_{T}$ is the total mass, $R_{\max }$ is the mean diameter of the largest aggregate, and $D$ is the aggregate fractal dimension. The mean aggregate diameter was taken as the arithmetic mean of the upper and lower sieve sizes, and the mean diameter of the aggregates $<0.002 \mathrm{~mm}$ was taken as $0.001 \mathrm{~mm}$.

\section{Statistical Analysis}

The data were expressed as means \pm standard deviations. One-way analysis of variance was performed by SPSS 18.0. Differences between means (at $P<0.05$ ) were tested by multiple comparisons using the least significant difference test. Regression models and graphs were prepared using SigmaPlot 10.0 (Systat Software, Inc., Chicago, USA).

\section{Results}

\section{Soil Properties and Crop Yield under Different Fertilizer Treatments}

Soil properties showed significant differences between the treatments containing manure (M, MN, MP, and MNP) and only with chemical fertilizers $(\mathrm{N}, \mathrm{P}$, and NP) $(P<0.05$; Table 2). The contents of SOC, TN, and MBC were higher 
Table 2. Soil properties under different fertilization treatments.

\begin{tabular}{|c|c|c|c|c|c|c|}
\hline Treatment & SOC $\left(\mathrm{g} \mathrm{kg}^{-1}\right)$ & $\mathrm{TN}\left(\mathrm{g} \mathrm{kg}^{-1}\right)$ & MBC $\left(\mathrm{mm} \mathrm{kg}^{-1}\right)$ & Clay $(\%)$ & Silt $(\%)$ & Sand $(\%)$ \\
\hline $\mathrm{CK}$ & $7.06 \pm 0.66 \mathrm{c}$ & $0.63 \pm 0.02 \mathrm{~d}$ & $111.54 \pm 2.67 \mathrm{bc}$ & $11.13 \pm 1.19 \mathrm{a}$ & $27.13 \pm 2.50 \mathrm{ab}$ & $61.75 \pm 3.69 \mathrm{~b}$ \\
\hline $\mathrm{N}$ & $6.15 \pm 0.54 \mathrm{c}$ & $0.62 \pm 0.02 \mathrm{~d}$ & $86.76 \pm 12.63 \mathrm{c}$ & $10.92 \pm 0.99 \mathrm{ab}$ & $26.91 \pm 2.18 \mathrm{ab}$ & $62.17 \pm 3.17 \mathrm{~b}$ \\
\hline $\mathrm{P}$ & $7.17 \pm 0.40 \mathrm{c}$ & $0.64 \pm 0.03 \mathrm{~d}$ & $130.09 \pm 16.39 \mathrm{~b}$ & $10.17 \pm 0.16 \mathrm{abc}$ & $24.99 \pm 0.22 \mathrm{bc}$ & $64.83 \pm 0.38 \mathrm{ab}$ \\
\hline $\mathrm{NP}$ & $6.37 \pm 0.26 \mathrm{c}$ & $0.65 \pm 0.02 \mathrm{~d}$ & $111.04 \pm 11.65 \mathrm{bc}$ & $11.15 \pm 0.92 \mathrm{a}$ & $27.69 \pm 1.93 \mathrm{a}$ & $61.16 \pm 2.85 \mathrm{~b}$ \\
\hline $\mathrm{M}$ & $11.83 \pm 0.83 \mathrm{a}$ & $1.04 \pm 0.05 \mathrm{ab}$ & $171.00 \pm 23.71 \mathrm{a}$ & $10.31 \pm 0.01 \mathrm{abc}$ & $26.63 \pm 0.15 \mathrm{abc}$ & $63.06 \pm 0.15 \mathrm{ab}$ \\
\hline $\mathrm{MN}$ & $10.95 \pm 0.78 \mathrm{ab}$ & $0.98 \pm 0.03 \mathrm{bc}$ & $125.30 \pm 12.93 \mathrm{~b}$ & $9.94 \pm 0.72 \mathrm{abc}$ & $26.01 \pm 1.26 \mathrm{abc}$ & $64.05 \pm 1.95 \mathrm{ab}$ \\
\hline $\mathrm{MP}$ & $11.89 \pm 0.57 \mathrm{a}$ & $1.11 \pm 0.02 \mathrm{a}$ & $169.34 \pm 5.45 \mathrm{a}$ & $9.91 \pm 0.07 \mathrm{bc}$ & $25.76 \pm 0.45 \mathrm{abc}$ & $64.33 \pm 0.51 \mathrm{ab}$ \\
\hline $\mathrm{MNP}$ & $11.08 \pm 0.09 \mathrm{~b}$ & $0.95 \pm 0.01 \mathrm{c}$ & $185.67 \pm 17.96 \mathrm{a}$ & $9.16 \pm 0.31 \mathrm{c}$ & $24.16 \pm 0.75 \mathrm{c}$ & $66.68 \pm 1.06 \mathrm{a}$ \\
\hline
\end{tabular}

in treatments containing manure than in the chemicalfertilizer treatments. Compared with $\mathrm{CK}$, SOC, TN, and $\mathrm{MBC}$ tended to increase in soils treated with manure. No remarkable differences in $\mathrm{SOC}, \mathrm{TN}, \mathrm{MBC}$, and soil particles were found among the treatments with N, P, NP, and CK $(P>0.05)$.

Fig. 1 shows the variation in crop yields among the eight treatments. Compared with $\mathrm{CK}$, the mean yield was $6.1-87.6 \%$ higher in the chemical-fertilizer treatments (N, P, and NP), and 90.9-151.5\% higher in the treatments containing manure (M, MN, MP, and MNP). Compared with CK, a significant increment in crop yield was observed among all fertilizer treatments except $\mathrm{N}$ and $\mathrm{P}(P<0.05)$. The highest crop yield was obtained in $\mathrm{MN}$ treatment, which was $151.5 \%$ higher than $\mathrm{CK}$ $(P<0.05)$.

\section{Soil Aggregate Stability under Different Fertilizer Treatments}

WSAs accounted for $37.8-57.7 \%$ of the dry soil weight in all treatments (Fig. 2). Compared with CK,

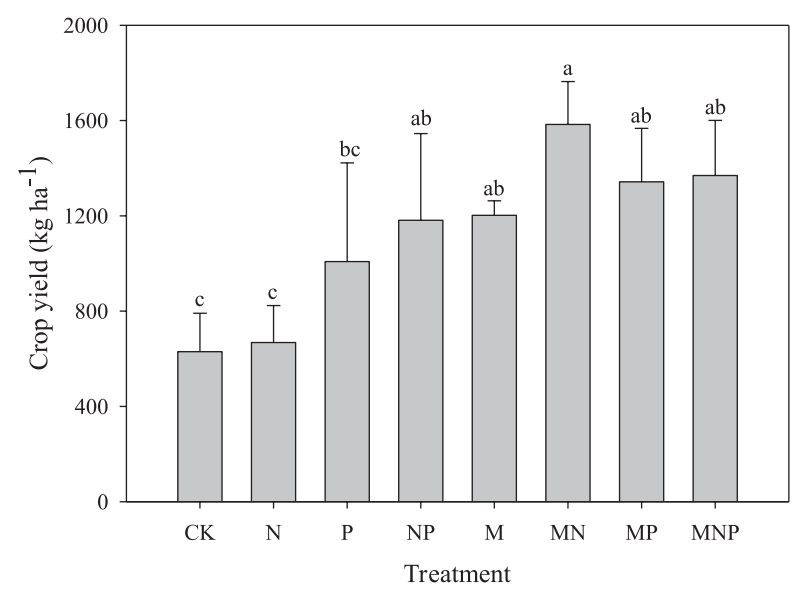

Fig. 1. Crop yield in the fertilization treatments. Different letters indicate significant differences at $P<0.05$. the proportions of WSAs were $6.2-17.5 \%$ lower in the $\mathrm{N}$, P, and NP treatments, but were $12.6-25.9 \%$ higher in the M, MN, MP, and MNP treatments. Of the treatments with both manure and chemical fertilizer, MNP had the lowest proportion of WSAs. In contrast, the treatment with manure alone had the highest proportion of WSAs.

As shown in Fig. 3, the chemical-fertilizer treatments caused 15.9-36.4\% decreases in MWD and 13.3-32.2\% decreases in GMD relative to CK. MWD and GMD were lowest in P treatment. In contrast, MWD and GMD were $22.8-43.3 \%$ and $4.3-20.0 \%$ higher, respectively, in the treatments containing manure relative to CK. For these treatments, MWD and GMD were highest in M treatment, although not statistically significant.

\section{Soil Aggregate Structure under Different Fertilizer Treatments}

Aggregate state (AS), aggregate degree (AD), and dispersion rate (DR) varied to some degree among the eight treatments (Fig. 4). Compared with CK, AS was 1.4-

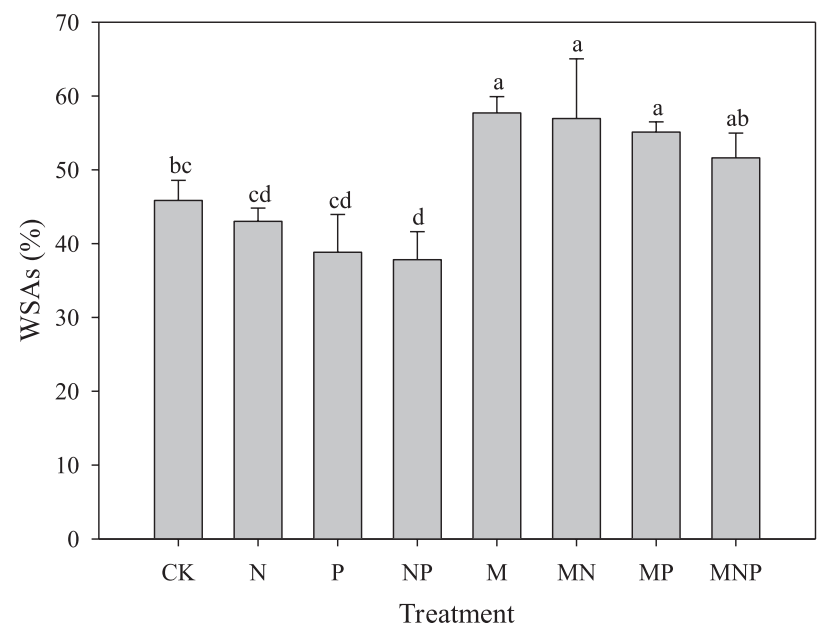

Fig. 2. Water-stable aggregates (WSAs) $(>0.25 \mathrm{~mm})$ in the fertilization treatments. Different letters indicate significant differences at $P<0.05$. 
$19.7 \%$ higher in $\mathrm{M}, \mathrm{MN}, \mathrm{MP}$, and MNP treatments and 4.4-21.5\% lower in N, P, and NP treatments. No significant difference was found among the fertilized treatments except P $(P>0.05$; Fig. 4a). AD was closely correlated with AS, and the lowest values both were obtained in $\mathrm{P}$ treatment among all fertilized treatments and $\mathrm{CK}$ (Fig. 4b). The changes in DR for all fertilized treatments, however, were opposite those of AS. The average DR was $6.1 \%$ lower for the treatments containing manure $(\mathrm{M}, \mathrm{MN}$, MP, and MNP) than for the chemical-fertilizer treatments (N, P, and NP; Fig. 4c).

Fig. 5 shows the variation in aggregate fractal dimension (D) among the eight treatments. The values of D were higher by $1.5-4.2 \%$ for the chemical-fertilizer treatments and lower by $0.4-2.9 \%$ for the treatments containing manure than for CK. Moreover, D was significantly negatively correlated with SOC, WSAs, and

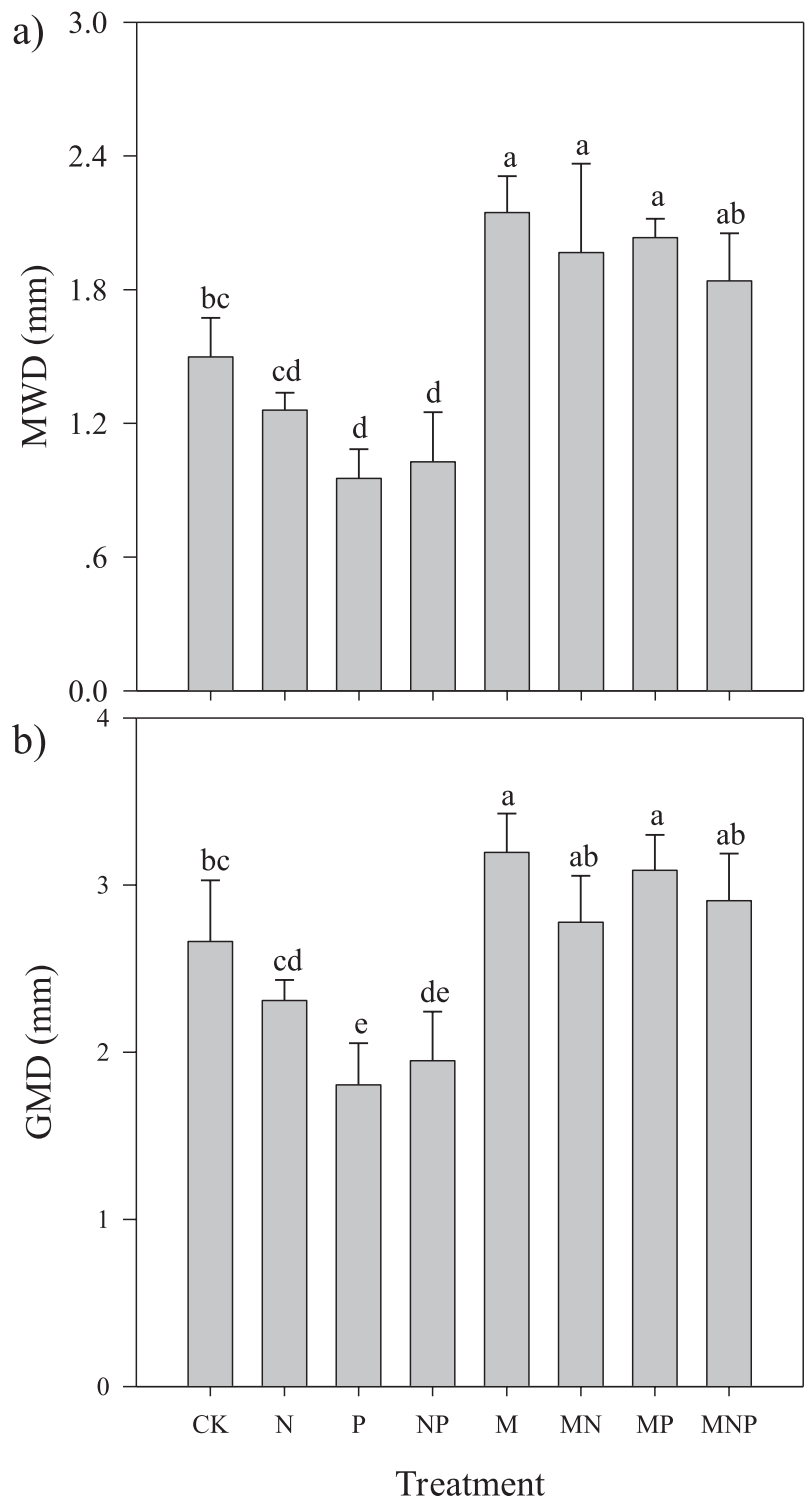

Fig. 3. Mean weight diameter (MWD) and geometric mean diameter (GMD) of soil aggregates in the fertilization treatments. Different letters indicate significant differences at $P<0.05$. aggregate state, but positively correlated with dispersion rate $(P<0.01$ or $P<0.05$; Fig. 6$)$.

\section{Discussion}

The MWD and GMD are crucial indicators of aggregate stability [14, 40]. The MWD reflects the proportion of macro aggregates [15], while the GMD estimates the size of the most frequent aggregate size class [41]. In our study, the result showed that the proportions of GMD and
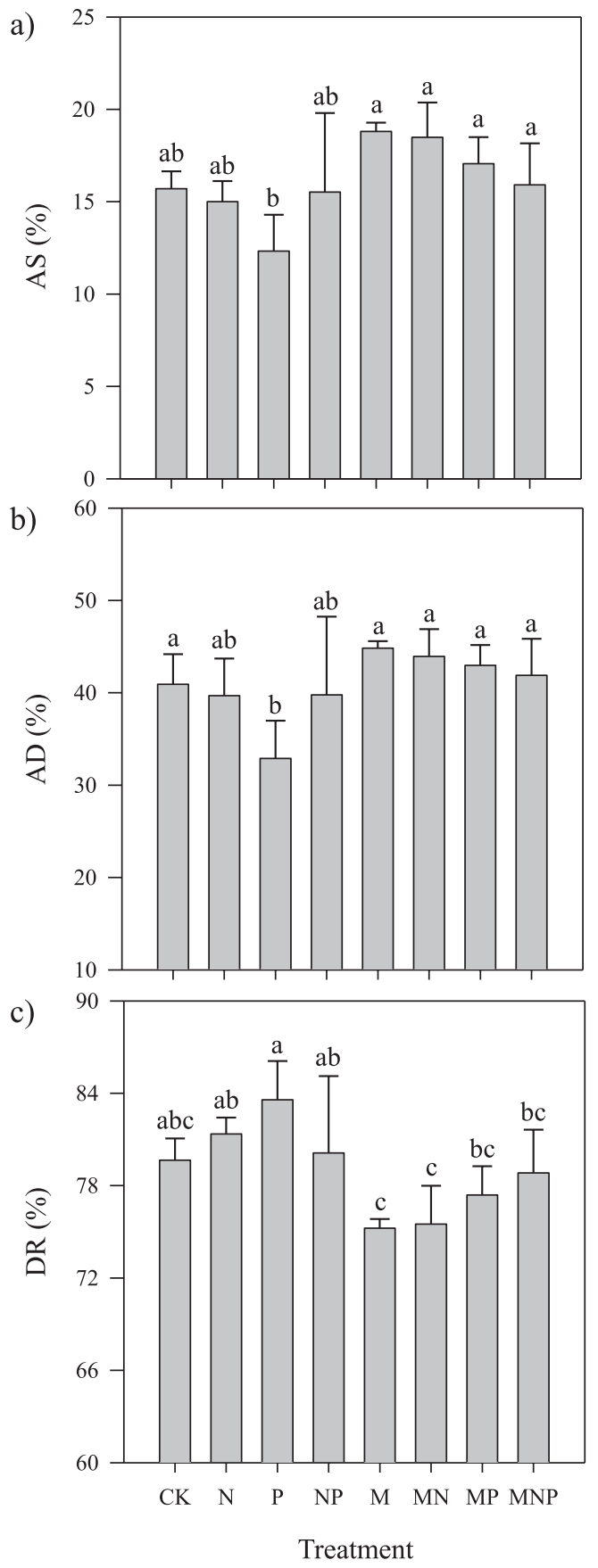

Fig. 4. Aggregate state (AS), aggregate degree (AD), and dispersion rate (DR) in the fertilization treatments. Different letters indicate significant differences at $P<0.05$. 


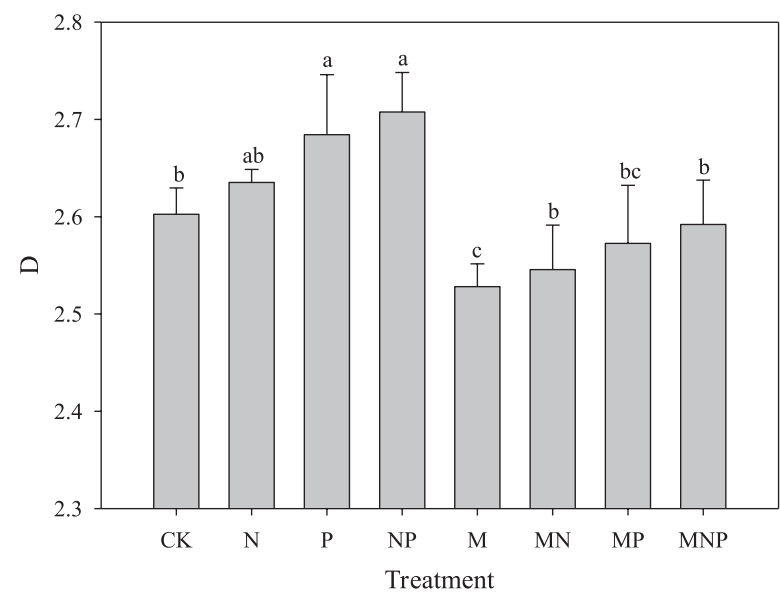

Fig. 5. Aggregate fractal dimension (D) in the fertilization treatments. Different letters indicate significant differences at $P<0.05$.

MWD were lower in the chemical-fertilizer treatments (N, $\mathrm{P}$, and NP) relative to $\mathrm{CK}$ (no fertilizer applied), consistent with the findings of Haynes and Naidu [10], who reported that chemical fertilizers have a negative influence on soil structure. In contrast, the MWD and GMD were significantly higher in soils treated with manure than in soils without manure [2].

Aggregate state (AS), aggregate degree (AD), and dispersion rate (DR) in our study were used to assess soil aggregate structure. The soils fertilized with both manure and chemical fertilizer showed a higher soil structure than soils treated with chemical fertilizer only (Fig. 4). These results were consistent with those of previous studies. Naveed et al. [3], using X-ray computed tomography, reported an obvious improvement in soil structure (wider
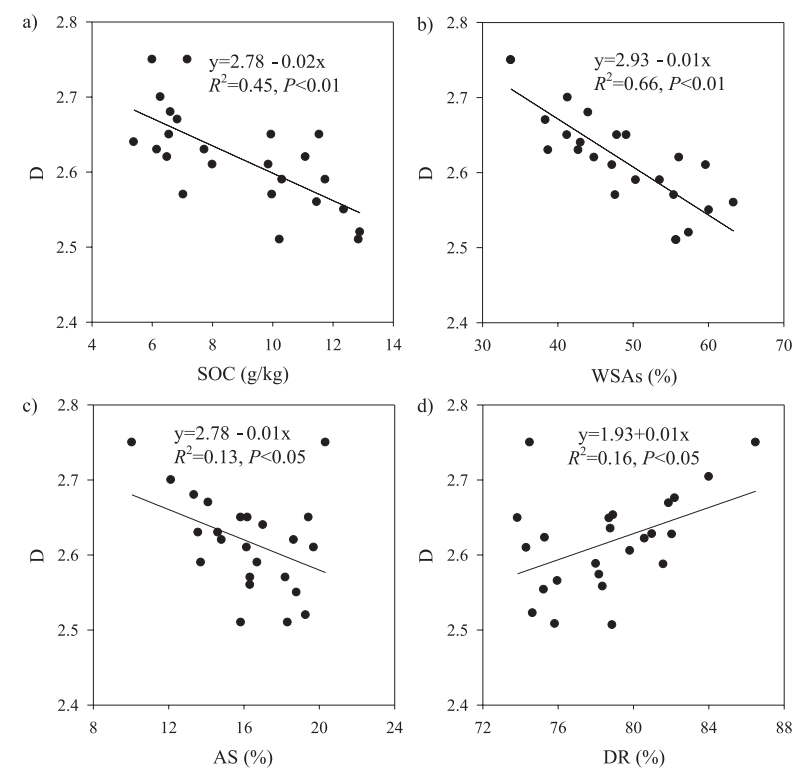

Fig. 6. Correlations between aggregate fractal dimension (D) and soil organic carbon (SOC), water-stable aggregates (WSAs), aggregate state (AS), and dispersion rate (DR).

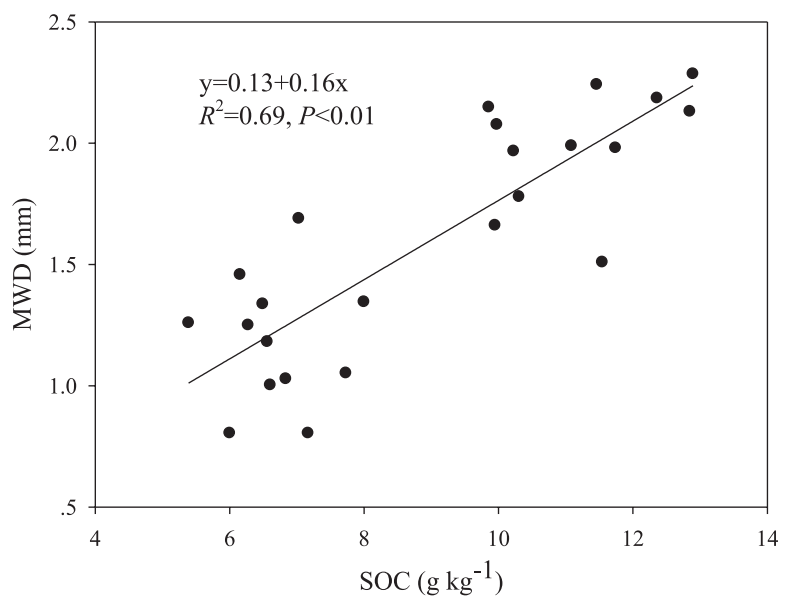

Fig. 7. Correlation between mean weight diameter (MWD) and soil organic carbon (SOC) content.

distribution of pore sizes, higher pore connectivity, and higher biological activity) and related soil functions with increasing animal manure. Yang et al. [7] found that the application of manure increased the penetration resistance and shear strength of bulk soil.

The application of manure generally increases SOC content more than other fertilizer treatments (Table 2) supported by other reports [6, 42-43]. However, organic fertilizers affect soil aggregate stability and structure mainly through their effects on organic matter [7, 1314]. Our results demonstrated that MWD was positively correlated with SOC content $(P<0.01$; Fig. 7). Organic fertilizers could lead to an increase in the proportion of WSAs, which was attributed to the input of additional organic residues and available $\mathrm{C}$ compared with that by the application of chemical fertilizers [2, 30, 44]. Furthermore, microbial biomass plays a fundamental role in soil organic matter by facilitating key functions and services such as soil aggregation, decomposition, and organic carbon mineralization [45-46]. Higher levels of SOC increase the availability of $\mathrm{C}$ substrates that stimulate microbial activity [46-48]. Microbial biomass contributes to $\mathrm{C}$ sequestration by producing polysaccharides and fungal hyphae that improve soil aggregation [49-51]. In contrast, the longterm application of chemical fertilizers may suppress microbial biomass, resulting in a substantial reduction in MBC and SOC accumulation [52]. Khan et al. [53] reported that $\mathrm{N}$ fertilizers increased SOC mineralization. In our study, the application of chemical fertilizers tend to increase crop yields (Fig. 1), but do not guarantee an increase in $\mathrm{MBC}$ and $\mathrm{SOC}$ contents, thus the aggregate stability of chemical-fertilizer treatments were slightly lower than that for CK. As a result, aggregate stability was lower in soil fertilized with chemical fertilizers than in soil fertilized with manure [15-16].

The heterogeneity of soil structure due to the distribution of aggregate sizes has recently been described by the fragmentation of fractal dimension [54]. Many factors that influence the fractal dimension include vegetation and erosion [19, 55-57]. Our results showed 
that a combination of organic and inorganic fertilizers could decrease the aggregate fractal dimension (Fig. 5). The decrease may be attributed to the increase in the proportion of aggregates $>5 \mathrm{~mm}$ with the input of an additional $\mathrm{C}$ source. Furthermore, fractal dimension was significantly correlated with SOC, WSAs, aggregate sate, and dispersion rate $(P<0.01$ or $P<0.05$; Fig. 6). Aggregate fractal dimension can thus indicate changes in soil structure associated with the long-term application of fertilizer in loessial soil [19].

\section{Conclusion}

The effects of fertilizers on soil aggregate stability and structure depend on the fertilizer type. Continuous application of manure (M), either alone or in combination with $\mathrm{N}$ and/or $\mathrm{P}$, can increase water-stable aggregates (WSAs), mean weight diameter (MWD), geometric mean diameter (GMD), aggregate state (AS), and aggregate degree (AD). In contrast, the long-term application of $\mathrm{NP}$, or $\mathrm{N}$ and $\mathrm{P}$ individually has lower values of these indexes than $\mathrm{CK}$. The differences may be attributed to $\mathrm{C}$ source and microbial biomass, which cause differences in fungal hyphae in the loessial soil. Of the treatments in all fertilizers and CK, $\mathrm{M}$ had the highest proportion of WSAs, MWD, GMD, AS, and AD. Chemical fertilizers could increase crop yield, but did not improve soil structure. The present study indicated that the application of manure was a preferred strategy for improving soil fertility and for sustainable soil management in the Loess Plateau of China.

\section{Acknowledgements}

This research was financially supported by the key deployment project of the Chinese Academy of Sciences (KJZD-EW-TZ-G10), the Special Program for Basic Research of the Ministry of Science and Technology in China (2014FY210100), and the National Natural Science Foundation of China (41171422).

\section{References}

1. BRONICK C.J., LAL R. Soil structure and management: a review. Geoderma. 124 (1-2), 3, 2005.

2. MENG Q.F., SUN Y.T., ZHAO J., ZHOU L.R., MA X.F., ZHOU M., GAO W., WANG G.C. Distribution of carbon and nitrogen in water-stable aggregates and soil stability under long-term manure application in solonetzic soils of the Songnen plain, northeast China. J. Soil Sediment. 14 (6), 1041, 2014.

3. NAVEED M., MOLDRUP P., VOGEL H.J., LAMANDÉ M., WILDENSCHILD D., TULLER M., JONGE L.W.D. Impact of long-term fertilization practice on soil structure evolution. Geoderma. 217, 181, 2014.

4. CAMPELLC.A, SELLES F., LAFOND G.P., BIEDERBECK V.O., ZENTNER R.P. Tillage-Fertilizer changes: effect on soil quality attributes under long-term crop rotations in a thin
Black Chernozem. Can. J. Soil Sci. 81 (2), 157, 2001.

5. SU Y.Z., WANG F., SUO D.R., ZHANG Z.H., DU M.W. Long-term effect of fertilizer and manure application on soil-carbon sequestration and soil fertility under the wheatwheat-maize cropping system in northwest China. Nutr. Cycl. Agroecosys. 75 (1), 285, 2006.

6. EFTHIMIADOU A., BILALIS D., KARKANIS A., FROUD-WILLIAMS B. Combined organic/inorganic fertilization enhance soil quality and increased yield, photosynthesis and sustainability of sweet maize crop. Aust. J. Crop Sci. 4 (9), 722, 2010.

7. YANG W., LI Z.X., CAI C.F., GUO Z.L., CHEN J.Z., WANG J.G. Mechanical properties and soil stability affected by fertilizer treatments for an Ultisol in subtropical China. Plant Soil. 363 (1), 157, 2013.

8. MAZUR Z., MAZUR T. Effects of long-term organic and mineral fertilizer applications on soil nitrogen content. Pol. J. Environ. Stud. 24 (5), 2073, 2015.

9. LI Q., XU M.X., LIU G.B., ZHAO Y.G., TUO D.F. Cumulative effects of a 17-year chemical fertilization on the soil quality of cropping system in the Loess Hilly Region, China. J. Plant Nutr. Soil Sc. 176 (2), 249, 2013.

10. HAYNES R.J., NAIDU R. 1998. Influence of lime, fertilizer and manure applications on soil organic matter content and soil physical conditions: a review. Nutr. Cycl. Agroecosys. 51 (2), 123, 1998.

11. SIMANSKY V., TOBIASOVA E., CHLPIK J. Soil tillage and fertilization of Orthic Luvisol and their influence on chemical properties, soil structure stability and carbon distribution in water-stable macroaggregates. Soil Till. Res. 100 (1), 125, 2008

12. MUNKHOLM L.J., SCHJONNING P., DEBOSZ K., JENSEN H.E., CHRISTENSEN B.T. Aggregate strength and mechanical behavior of a sandy loam soil under longterm fertilization treatments. Eur. J. Soil Sci. 53 (1), 129, 2002.

13. RASOOL R., KUKAL S.S., HIRA G.S. Soil organic carbon and physical properties as affected by long-term application of FYM and inorganic fertilizers in maize-wheat system. Soil Till. Res. 101, 31, 2008.

14. LIU Z.X., CHEN X.M., JING Y., LI Q.X., ZHANG J.B., HUANG Q.R. Effects of biochar amendment on rapeseed and sweet potato yields and water stable aggregate in upland red soil. Catena. 123, 45, 2014.

15. KIHARA J.A., BATIONO D.N., MUGENDI C., MARTIUS C., VLEK P.L.G. 2011. Conservation tillage, local organic resources and nitrogen fertilizer combinations affect maize productivity, soil structure and nutrient balances in semi-arid Kenya. Nutr. Cycl. Agroecosys. 90 (2), 213, 2011.

16. YU H.Y., DING W.X., LUO J.F., GENG R.L., GHANI A., CAI C.Z. Effects of long-term compost and fertilizer application on stability of aggregate-associated organic carbon in an intensively cultivated sandy loam soil. Biol. Fert. Soils. 48 (3), 325, 2012.

17. VILLAR M.C., PETRIKOVA V., DÍAZ-RAVIÑA M., CARBALLAS T. Changes in soil microbial biomass and aggregate stability following burning and soil rehabilitation. Geoderma. 122 (1), 73, 2004.

18. ABIVEN S., MENASSERI S., CHENU C. The effects of organic inputs over time on soil aggregate stability-a literature analysis. Soil Biol. Biochem. 41 (1), 1, 2009.

19. ZHAO S.W., SU J., YANG Y.H., LIU N.N., WU J.S., SHANGGUAN Z.P. 2006. A fractal method of estimating soil structure changes under different vegetations on Ziwuling mountains of the Loess Plateau, China. J. Integr. Agr. 5 (7), 530, 2006. 
20. SIX J., PAUSTIAN K., ELLIOTT E.T., COMBRINK C. Soil structure and organic matter: I. Distribution of aggregatesize classes and aggregate-associated carbon. Soil Sci. Soc. Am. J. 64 (2), 681, 2000.

21. SEYBOLD C.A. Aggregate stability kit for soil quality assessments. Catena. 44 (1), 37, 2001.

22. BARTHES B., ROOSE E. Aggregate stability as an indicator of soil susceptibility to runoff and erosion; validation at several levels. Catena. 47 (2), 133, 2002.

23. XU M.X., ZHAO Y.G., LIU G.B., WILSON G. Identification of soil quality factors and indicators for the Loess Plateau of China. Soil Science. 171 (5), 400, 2006.

24. XIAO L., LIU G.B., XUE S., ZHANG C. Fractal features of soil profiles under different land use patterns on the Loess Plateau, China. J. Arid Land. 6 (5), 550, 2014.

25. PERRIER E., BIRD N., RIEU M. Generalizing the fractal model of soil structure: the pore-solid fractal approach. Geoderma. 88 (3-4), 137, 1999.

26. SU Y.Z., ZHAO H.L., ZHAO W.Z., ZHANG Z.H., DU M.W. Fractal features of soil particle-size distribution and the implication for indicating desertification. Geoderma. 122 (1), 43, 2004.

27. AHMADI A., NEYSHABOURI M.R., ROUHIPOUR H., ASADI H. Fractal dimension of soil aggregates as an index of soil erodibility. J. Hydrol. 400 (3-4), 305, 2011.

28. WANG L., LI J., LI J., BAI W.X. Effects of tillage rotation and fertilization on soil aggregates and organic carbon content in cornfield in Weibei Highland. Chinese Journal of Applied Ecology. 25 (5), 759, 2014 [In Chinese].

29. QIU L.P., ZHANG X.C., CHENG J.M. Effects of 22 years of re-vegetation on soil quality in the semi-arid area of the Loess Plateau. Afr. J. Biotechnol. 8 (24), 6896, 2009.

30. YANG Z.H., SINGH B.R., HANSEN S. Aggregate associated carbon, nitrogen and sulfur and their ratios in long-term fertilized soils. Soil Till. Res. 95 (1-2), 161, 2007.

31. RASMUSSEN P.E., GOULDING K.W.T., BROWN J.R., GRACE P.R., JANZEN H.H., KORSCHENS M. Longterm agroecosystem experiments: assessing agricultural sustainability and global change. Science. 282 (5390), 893, 1998.

32. LI Y.Y., SHAO X.H., GUAN W.L., REN L., LIU J., WANG J.L., WU Q.J. Nitrogen-decreasing and yield-increasing effects of combined applications of organic and inorganic fertilizers under controlled irrigation in a paddy field. Pol. J. Environ. Stud. 25 (2), 673, 2016.

33. ZHANG C., LIU G.B., XUE S., SUN C.L. Soil organic carbon and total nitrogen storage as affected by land use in a small watershed of the Loess Plateau, China. Eur. J. Soil Sci. 54, 16, 2013.

34. YODER R.E. A direct method of aggregate analysis of soils and study of the physical nature of soil erosion losses. Amer. Soc. Agronomy. 28, 337, 1936.

35. ZHANG C., LIU G.B., XUE S., SONG Z.L., ZHANG C.S. Fractal features of rhizosphere soil microaggregate and particle-size distribution under different vegetation types in the hilly-gully region of Loess Plateau. Scientia Agricultura Sinica. 44 (3), 507, 2011 [In Chinese].

36. NELSON D.W., SOMMERS L.E. Total carbon, organic carbon, and organic matter. Agronomy monograph 9. In: Page A.L., Miller R.H., Keeney D.R. (eds) Methods of soil analysis, part 2, chemical and microbial properties. Madison, Wisconsin: Agronomy Society of America, 539, 1982.

37. BREMNER J.M., MULVANEY C.S. Nitrogen-total. Agronomy monograph 9. In: Methods of soil analysis, part 2, chemical and microbial properties. Madison, Wisconsin: Agronomy Society of America, 595, 1982.
38. VANCE E.D., BROOKES P.C., JENKINSON D.S. An extraction method for measuring microbial biomass C. Soil Biol. Biochem. 19 (6), 703, 1987.

39. TUO D.F., XU M.X., ZHAO Y.G., GAO L.Q. Interactions between wind and water erosion change sediment yield and particle distribution under simulated conditions. J. Arid Land. 7 (5), 590, 2015.

40. KEMPER W.D., CHEPIL W.S. Size distribution of aggregation. In: Black CA (eds) Methods of Soil Analysis. American Society of Agronomy, Madison W.I., 499, 1965.

41. FILHO C.C., LOURENCO A., GUIMARAES F.M., FONSECA I.C.B. Aggregate stability under different soil management systems in a red latosol in the state of Parana, Brazil. Soil Till. Res. 65 (1), 45, 2002.

42. LI L.Q., ZHANG X.H., ZHANG P.J., ZHENG J.F., PAN G.X. Variation of organic carbon and nitrogen in aggregate size fractions of a paddy soil under fertilisation practices from Tai Lake Region, China. J. Sci. Food Agr. 87 (6), 1052, 2007.

43. YANG X.Y., LI P.R., ZHANG S.L., SUN B.H., CHEN X.P. Long-term-fertilization effects on soil organic carbon, physical properties, and wheat yield of a loess soil. J. Plant Nutr. Soil Sc. 174 (5), 775, 2011.

44. LI C.H., LI Y., TANG L.S. The effects of long-term fertilization on the accumulation of organic carbon in the deep soil profile of an oasis farmland. Plant Soil, 369 (1-2), 645, 2013.

45. MANZONI S., PORPORATO A. Soil carbon and nitrogen mineralization: Theory and models across scales. Soil Biol. Biochem. 41 (7), 1355, 2009.

46. SIX J., ELLIOTT E.T., PAUSTIAN K. Aggregate and soil organic matter dynamics under conventional and no-tillage systems. Soil Sci. Soc. Am. J. 63 (5), 1350, 1999.

47. AOYAMA M., ANGERS D.A., N'DAYEGAMIYE A. Particulate and mineral-associated organic matter in waterstable aggregates as affected by mineral fertilizer and manure applications. Can. J. Soil Sci. 79 (2), 295, 1999.

48. NAYAK D.R., BABU Y.J., ADHYA T.K. Long-term application of compost influences microbial biomass and enzyme activities in a tropical Aeric Endoaquept planted to rice under flooded condition. Soil Biol. Biochem. 39 (8), 1897, 2007.

49. BEDINI S., PELLEGRINO E., AVIO L., PELLEGRINI S., BAZZOFFI P., ARGESE E., GIOVANNETTI M. Changes in soil aggregation and glomalin-related soil protein content as affected by the arbuscular mycorrhizal fungal species Glomus mosseae and Glomus intraradices. Soil Biol. Biochem. 41 (7), 1491, 2009.

50. KALLENBACH C., GRANDY A.S. Controls over soil microbial biomass responses to carbon amendments in agricultural systems: A meta-analysis. Agr. Ecosyst Environ. 144 (1), 241, 2011.

51. HUA K.K., ZHU B., WANG X.G., GUO X.S., WANG D.Z., GUO Z.B. Effect of long-term fertilization on soil aggregateassociated dissolved organic nitrogen on sloping cropland of purple soil. Plant Soil Environ. 60 (2), 51, 2014.

52. TRESEDER K.K. Nitrogen additions and microbial biomass: A meta-analysis of ecosystem studies. Ecol. lett. 11 (10), 1111, 2008.

53. KHAN S.A., MULVANEY R.L., ELLSWORTH T.R., BOAST C.W. The myth of nitrogen fertilization for soil carbon sequestration. J. Environ. Qual. 36 (6), 1821, 2007.

54. PERFECT E., RASIAH V., KAY B.D. Fractal dimension of soil aggregate-size distributions calculated by number and mass. Soil Sci. Soc. Am. J. 56 (5), 1407, 1992. 
55. WANG X.D., LI M.H., LIU S.Z., LIU G.C. Fractal characteristics of soils under different land-use patterns in the arid and semiarid regions of the Tibetan Plateau, China. Geoderma. 134 (1-2), 56, 2006

56. XU G.C., LI Z.B., LI P. Fractal features of soil particle-size distribution and total soil nitrogen distribution in a typical watershed in the source area of the middle Dan River, China. Catena. 101, 17, 2013.

57. ZHANG G.H., LIU G.B., WANG G.L., WANG Y.X. Effects of vegetation cover and rainfall intensity on sediment-bound nutrient loss, size composition and volume fractal dimension of sediment particles. Pedosphere. 21 (5), 676, 2011. 